ZOOLOGIA 32 (3): 187-194, June 2015

http://dx.doi.org/10.1590/S1984-46702015000300002

\title{
Advertisement call of Dendropsophus microps (Anura: Hylidae) from two populations from southeastern Brazil
}

\author{
Lucas Rodriguez Forti ${ }^{1, *}$, Rafael Márquez ${ }^{2} \& J$ aime Bertoluci
}

\author{
${ }^{1}$ Programa de Pós-Graduação Interunidades em Ecologia Aplicada, Escola Superior de Agricultura Luiz de Queiroz, \\ Universidade de São Paulo. Avenida Centenário 303, $13400-970$ Piracicaba, SP, Brazil. \\ ${ }^{2}$ Fonoteca Zoológica, Departamento de Biodiversidad y Biología Evolutiva, Museo Nacional de Ciencias Naturales. \\ José Gutiérrez Abascal 2, Madrid, Spain. E-mail: rmarquez@mncn.csic.es \\ ${ }^{3}$ Departamento de Ciências Biológicas, Escola Superior de Agricultura Luiz de Queiroz, Universidade de São Paulo. \\ Avenida Pádua Dias 11, 13418-900 Piracicaba, SP, Brazil. E-mail: jaime.bertoluci@usp.br \\ *Corresponding author. E-mail: lucas_forti@yahoo.com.br
}

\begin{abstract}
In anurans, acoustic communication is a major mechanism of pre-zygotic isolation, since it carries information about species recognition. Detailed descriptions of the acoustic properties of anuran advertisement calls provide important data to taxonomist and to the understanding of the evolution of the group. Herein we re-describe the advertisement call of the hylid frog Dendropsophus microps (Peters, 1872) after analyzing a larger sample than that of previous descriptions. We also compare the acoustic properties of the call in two populations and discuss the effect of the presence of the sister species, Dendropsophus giesleri (Mertens, 1950), a potential competitor, in one of the populations. Additionally, we provide information on calling sites and size of males. Males of $D$. microps emit two types of calls, which differ mainly in pulse repetition rate. Type " $A$ " call has a mean frequency band varying from 4574 to $5452 \mathrm{~Hz}$, (mean dominant frequency $=4972 \mathrm{~Hz}$ ). Type " $\mathrm{B}$ " call has a mean frequency band varying from 4488 to $5417 \mathrm{~Hz}$ (mean dominant frequency $=4913 \mathrm{~Hz}$ ). The calls of $D$. microps and $D$. giesleri are the only in the $D$. parviceps species group that have harmonic structure. The spectral properties of the call showed low intra-individual variation, being considered static, while the temporal properties were highly variable. Compared with males from the Boracéia population, males from the Ribeirão Grande population called from lower perches, and their calls had slightly lower frequency bands and significantly higher pulse rates in their type " $B$ " calls. Inter-populational differences in acoustic properties, body size and use of calling sites could be related to selective forces associated with the presence of the sister species, a potential competitor for the population from Ribeirão Grande.
\end{abstract}

KEY WORDS. Acoustic traits; Amphibia; bioacoustics; call evolution; competition.

Anuran vocalizations play a key role in mate recognition and may correspond to their main pre-zygotic isolation mechanism, besides being an essential component of sexual selection (GERHARDT 1994, Wells 1977). Given the complex acoustic repertoires (Toledo \& Haddad 2005, Forti et al. 2010, Morais et al. 2012) of frog species, it is likely that accurate quantitative descriptions of anuran advertisement calls will help to solve taxonomic problems and to recover the relationships among taxa (Ryan \& Rand 1993, Wells 2007). The advertisement calls of many anuran species have been described. However, sample sizes for these descriptions are often small, which limits their usefulness, since intraspecific variation may not be sufficiently accounted for. For this reason, re-descriptions of advertisement calls based on larger sample sizes are needed. Larger samples sizes are also important to quantify among population variations, and to understand how the advertisement call has evolved in a given species (GERHARDT 2012). Many factors can cause evolutionary changes in the properties of the call, and one of the fundamental sources of among population variation is acoustic interaction between sister species (Littlejohn 1976, Höвel \& Gerhardt 2003, GERHARDT 2012). The presence of similar species calling on the same reproductive habitat may represent a selective pressure on call properties. Differences in them are expected to improve the quality of co-specific communication and to prevent the formation of heterospecific couples (HADDAD et al. 1994, HöBEL \& GERHARDT 2003).

Herein we re-describe the advertisement call of the hylid species Dendropsophus microps (Peters, 1872), using data from two populations, and provide measurements of intra-individual and intra-population variation from a large sample. We also compare the acoustic properties of the call and their variations between two populations and discuss the effect of the presence

2015 | Sociedade Brasileira de Zoologia | www.sbzoologia.org.br | www.scielo.br/zool All content of the journal, except where identified, is licensed under a Creative Commons attribution-type BY-NC. 
of the sister species and potential competitor, Dendropsophus giesleri (Mertens, 1950), in one of them. Additionally we provide information on male body size and calling sites.

\section{MATERIAL AND METHODS}

The hylid frog Dendropsophus microps belongs to the $D$. parviceps group, whose species occur mainly in the Amazon region, with two exceptions, $D$. giesleri, and $D$. microps, which occur in the Atlantic forest (FAivovich et al. 2005, Frost 2014). The natural habits of the species of the group are poorly known.

Dendropsophus microps (Figs. 1-2) is distributed from the southern portion of the of state Bahia to the northern portion of the state of Rio Grande do Sul, southeastern Brazil, in areas of Atlantic forest and adjacent Cerrado (Frost 2014). Its advertisement call was described from a single male recorded from Teresópolis, state of Rio de Janeiro (Heyer 1980), and from a male from Boracéia, state of São Paulo (Heyer et al. 1990).

Data were collected from two sites in the Atlantic forest, state of São Paulo, southeastern Brazil. Both sites are located within the mountain complex of Serra do Mar, which is characterized by high levels of rainfall and exuberant evergreen vegetation. Males were recorded in two reproductive sites within the Boracéia Biological Station, at 847 and 872 masl, in the municipality of Biritiba Mirim ( $23^{\circ} 37^{\prime} \mathrm{S}, 45^{\circ} 52^{\prime} \mathrm{W}$ ) (for more complete descriptions of the site see: Heyer et al. 1990), and also in two breeding sites in the Parque Estadual Intervales (791 and 864 masl), municipality of Ribeirão Grande $\left(24^{\circ} 15^{\prime} \mathrm{S}, 48^{\circ} 24^{\prime} \mathrm{W}\right)$ - for more complete descriptions of the site see Bertoluci \& Rodrigues (2002).

Recordings of a total of 20 males of $D$. microps were obtained from the two localities mentioned above.

The abiotic conditions during call recordings are listed in Table 1 . Male calling sites were characterized by perch nature and height from the water surface. Digital recordings were made at a sampling rate of $48 \mathrm{kHz}$ and 16 bit resolution with a Marantz PMD660 recorder and a Yoga EM 9600 microphone positioned about $80-60 \mathrm{~cm}$ from the calling males. The analysis of acoustic properties of 124 calls were completed with Raven pro 641.4 software for Windows (Cornell Lab of Ornithology), using FFT (Fast Fourier Transformation) $=1024$ and Overlap $=$ 50. We analyzed the following call properties: highest frequency of call A (HFCA), highest frequency of call B (HFCB), lowest frequency of call A (LFCA), lowest frequency of call B (LFCB),
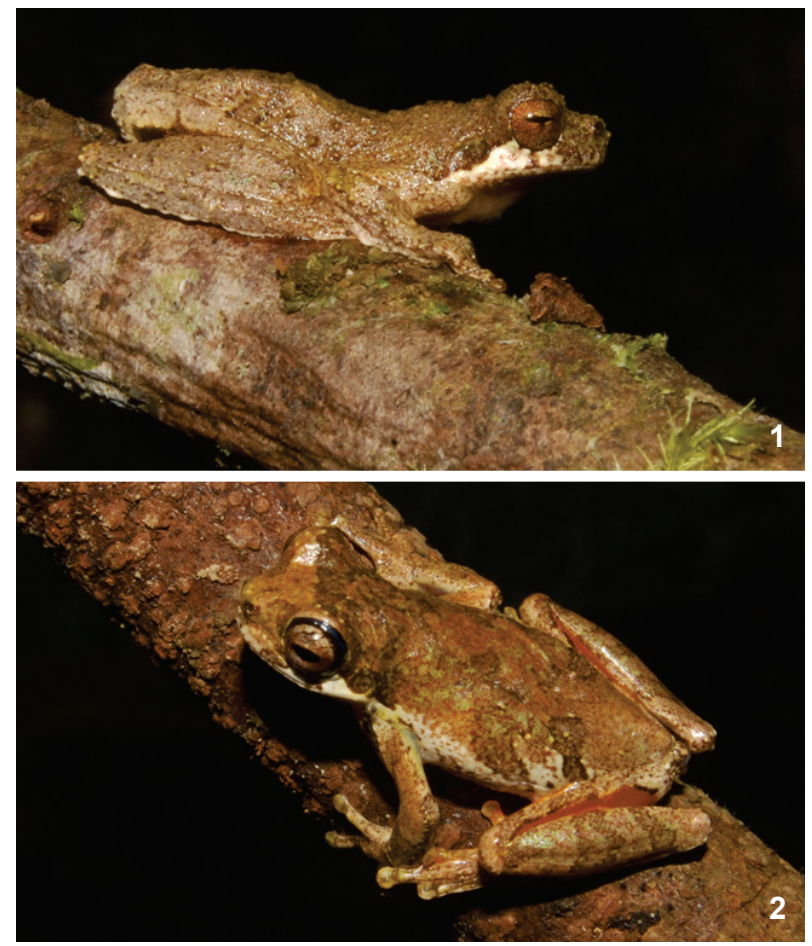

Figures 1-2. Males of Dendropsophus microps from Boracéia (1) and Ribeirão Grande (2), São Paulo state, southeastern Brazil.

dominant frequency of call A (DFCA), dominant frequency of call B (DFCB), duration of the first note of call A (DFNCA), duration of call $\mathrm{B}(\mathrm{DCB})$, pulses rate of the first note of call $\mathrm{A}$ (PRFNCA) and pulses rate of call B (PRCB). The spectral measurements were obtained by selecting three variables in the menu "choose measurements" in Raven 1.4: (1) Frequency 5\% $(\mathrm{Hz})$, (2) Frequency 95\% (Hz) - these two measurements include highest frequency and lowest frequency, ignoring 5\% downward and upward over the frequency band formed by the distribution of energy; and (3) Max Frequency (Hz) - it shows the dominant frequency (the frequency in which the power is maximum within the call). The snout-vent length (SVL) of the calling males was measured with digital calipers (to the nearest $0.1 \mathrm{~mm}$ ). Eleven individuals were collected and were deposited as voucher specimens in the Herpetological Collection of Escola Superior de Agricultura Luiz de Queiroz,

Table 1. Abiotic conditions during call recordings of Dendropsophus microps in the two localities. Values presented as mean \pm standard deviation (range).

\begin{tabular}{lll}
\hline \multicolumn{1}{c}{ Abiotic variables } & \multicolumn{1}{c}{ Boracéia $(\mathrm{N}=9)$} & \multicolumn{1}{c}{ Ribeirão Grande $(\mathrm{N}=11)$} \\
\hline Air temperature $\left({ }^{\circ} \mathrm{C}\right)$ & $15.5 \pm 2.2(13-20.2)$ & $15.5 \pm 2.1(12.5-18.6)$ \\
Air humidity $(\%)$ & $89.3 \pm 2.9(85-93)$ & $90.3 \pm 2.9(84-93)$ \\
Recording period & $7: 30-9: 25$ p.m. & $7: 10-10: 20$ p.m. \\
Recording date & October 19-22th 2010 and January 13th 2011 & October 27-31th 2010 and February 7-9th 2011 \\
\hline
\end{tabular}

ZOOLOGIA 32 (3): 187-194, June 2015 
Universidade de São Paulo, Brazil (ICMBio license number 23799-1), with the accessing codes VESALQ 572, 698, 802, 811, $838,848,856,922,938,943$, and 985 . Acoustic recordings of 13 males were deposited in the Fonoteca Neotropical Jacques Vielliard with collection numbers 30876 to 30888 .

Two-sample T-tests (with 0.06 significance level) were used to detect significant differences between the types of call considering pulse repetition rate, and between population average considering body size $(\mathrm{mm})$, calling perch $(\mathrm{cm})$ and all call properties mentioned above.

Quantitative acoustic variables were calculated through descriptive statistics including coefficient of variation (SD/ mean) for intra-individual and intra-population levels. All the statistical analysis was carried out in the software SYSTAT 13.

\section{RESULTS}

\section{Body size}

Male SVL values were significantly greater in Ribeirão Grande $(24.3 \pm 1.7 \mathrm{~mm})$ than in Boracéia $(22.5 \pm 1.1 \mathrm{~mm})(\mathrm{N}=$ $18, \mathrm{t}=-2.578, \mathrm{p}<0.06)$.

\section{Calling perches}

Males of both populations called in or near lentic water bodies. In the population of Boracéia, males used mainly the adjacent vegetation $(75 \%, \mathrm{~N}=11)$ as calling perches, while in Ribeirão Grande, males also called from the emergent vegetation $(45 \%, N=8)$. Males from Boracéia called from higher perches (average of $71 \pm 36.9 \mathrm{~cm}$ ) than males from Ribeirão Grande (average of $43 \pm 20.3 \mathrm{~cm})(\mathrm{N}=19, \mathrm{t}=2.126, \mathrm{p}<0.06)$.

\section{Acoustic analysis}

Dendropsophus microps has two call types that are distinct in their pulse repetition rate $(\mathrm{N}=19, \mathrm{t}=6.625, \mathrm{p}<0.01)$. Type "A" calls have a pulse rate of $60-203$ pulses/s $(\mathrm{N}=34)$, and type "B" calls have a pulse rate of 23-60 pulses/s $(\mathrm{N}=45)$. Type "A" calls are formed by one to five notes, with a considerable range in duration (0.08-1.93 s, N =29) and two kinds of pulse structures: one longer with fused pulses and the other short with evident pulses (Figs. 3-4). We considered "note" an uninterrupted sound element that compose the call. Type " $\mathrm{B}$ " call is formed by a single pulse train, with average duration of $0.67 \mathrm{~s}$, (range 0.17-2.29 s, $\mathrm{N}=46$ ) (Fig. 5-6).
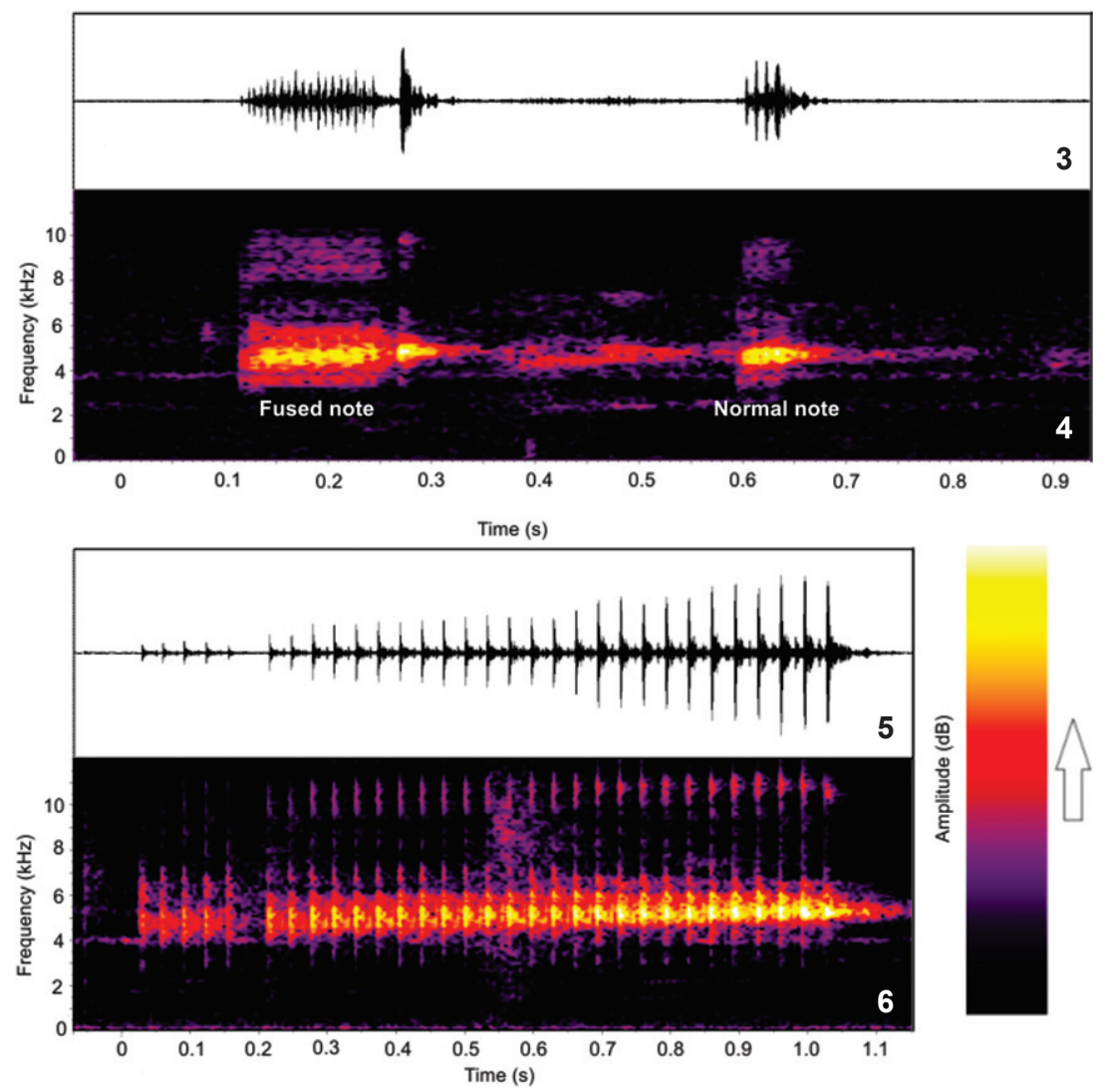

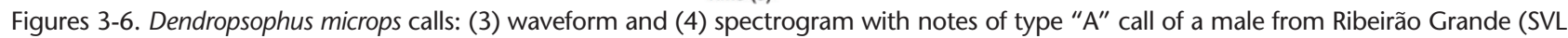
$22.1 \mathrm{~mm}$ ), recorded at 7:45 p.m. on February 9 th 2011 ; air temperature $=19.6^{\circ} \mathrm{C}$; air humidity $=88 \%$; (5) waveform and (6) spectrogram of type "B" call of a male from Boracéia (SVL $21.2 \mathrm{~mm}$ ), recorded at 7:47 p.m. on October 19th 2010; air temperature $=15^{\circ} \mathrm{C}$, air humidity $=85 \%$. 
Both call types have slight upward frequency modulation and increasing intensity. The average frequency band of both call types was similar: call type "A" 4574-5452 Hz ( $\mathrm{N}=$ 10), average dominant frequency $4972 \pm 195 \mathrm{~Hz}(\mathrm{~N}=10)$; call type "B" 4488-5417 Hz ( $=13)$, average dominant frequency $4913 \pm 242 \mathrm{~Hz}(\mathrm{~N}=13)$. Both call types showed a less intense harmonic band between 8000 and $11500 \mathrm{~Hz}$. More than one half of the recorded males emitted both call types (A and B) in the same call sequence (64\%). The emission proportion of both call types inside the same sequence was similar in both populations (57\% in males from Boracéia and $71 \%$ in males from Ribeirão Grande).

Many quantitative traits of calls were similar between the populations from Boracéia and Ribeirão Grande, but in call B we found significant differences between populations in highest frequency, duration, and pulse rate. Quantitative acoustical data and the results of statistical tests are presented in Table 2.

\section{Variation of acoustic properties}

In general, spectral acoustic properties are less variable than temporal properties in Dendropsophus microps (Figs. 7-9). The majority of call traits, both in the intra-individual and intra-population levels related to frequency showed coefficients of variation below 12\% and may be considered "static" (those below 5\%) or "intermediary" (more than 5\% and less than 12\% of variation) sensu GERHARDT (1991) (Figs. 7 and 9). On the other hand, all temporal properties measured, at the intra-individual level, showed CVs higher than that value and could be considered "dynamic" Gerhardt (1991) (Fig. 8).

The variation in spectral acoustic properties followed a similar pattern between populations. However, variations in some temporal properties were different between populations, as pulse rate of both types of call (Fig. 9). Pulse rate of call B (PRCB) in the population of Ribeirão Grande was the only temporal variable considered "static" at the population level.

\section{DISCUSSION}

\section{Body size}

The mean SVL of Dendropsophus microps males from Boracéia was $22.5 \mathrm{~mm}$, consistent with the results of Heyer et al. (1990) for the same locality. The differences in SVL between the two populations of this study may be associated with the selective pressure on morphological or acoustical traits caused by the sister species, $D$. giesleri, living in sympatry with the Ribeirão Grande population. Reproductive isolation in anuran species is expected to occur at the acoustic level rather than body size. However, selection may act on pleitropic genes that affect both size and call frequency. Pfennig \& Pfennig (2005) observed that Spea multiplicata (Scaphiopodidae) individuals were smaller in areas where they were sympatric with Spea bombifrons. They concluded that this difference was the result
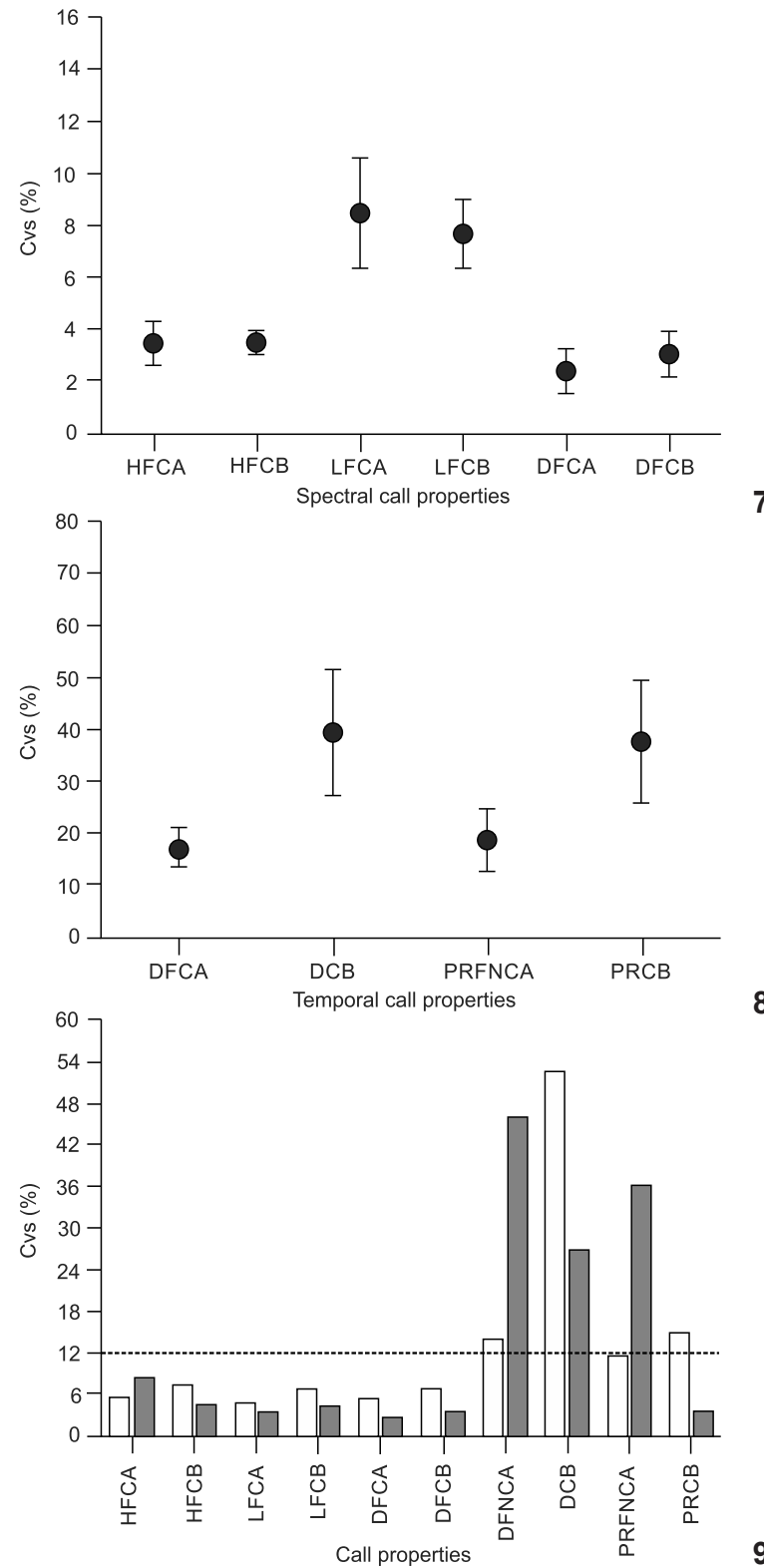

8

Figures 7-9. Intraindividual coefficient of variation (\%) of Dendropsophus microps spectral (7) and temporal (8) call properties. Error bars represent the confidence interval of $95 \%$ around the average (black circles). Intrapopulational coefficient of variation (\%) of $D$. microps call properties of the two populations studied (9). The red dashed line separates dynamic (above $12 \%$ of variation) and static acoustic properties sensu Gerhardt (2001). Abbreviations: highest frequency of call $A$ (HFCA), highest frequency of call $B$ (HFCB), lowest frequency of call $A$ (LFCA), lowest frequency of call $B$ (LFCB), dominant frequency of call $A$ (DFCA), dominant frequency of call $B$ (DFCB), duration of the first note of call $A$ (DFNCA), duration of call $B(D C B)$, pulses rate of the first note of call A (PRFNCA) and pulses rate of call B (PRCB). ( $\square$ ) Boracéia, ( $\square$ ) Ribeirão Grande 
Table 2. Call properties of the two populations of Dendropsophus microps studied. The values represent mean $\pm \mathrm{SD}$, and $\mathrm{N}=\mathrm{number}$ of males. Results of the two-sample t-tests are included.

\begin{tabular}{lcccc}
\hline \multicolumn{1}{c}{ Acoustic Properties } & Boracéia & Ribeirão Grande & t-value & p-value \\
\hline Highest frequency of call A $(\mathrm{Hz})$ & $5532 \pm 277(\mathrm{~N}=4)$ & $5398 \pm 422(\mathrm{~N}=6)$ & 0.604 & 0.562 \\
Highest frequency of call B (Hz) & $5580 \pm 377(\mathrm{~N}=7)$ & $5226 \pm 203(\mathrm{~N}=6)$ & 2.145 & $0.059^{*}$ \\
Lowest frequency of call A (Hz) & $4664 \pm 191(\mathrm{~N}=4)$ & $4513 \pm \mathrm{m} 129(\mathrm{~N}=6)$ & 1.385 & 0.227 \\
Lowest frequency of call B $(\mathrm{Hz})$ & $4513 \pm 283(\mathrm{~N}=7)$ & $4458 \pm 168(\mathrm{~N}=6)$ & 0.430 & 0.676 \\
Dominant frequency of call A (Hz) & $5109 \pm 237(\mathrm{~N}=4)$ & $4880 \pm 96(\mathrm{~N}=6)$ & 1.834 & 0.147 \\
Dominant frequency of call B (Hz) & $4944 \pm 311(\mathrm{~N}=7)$ & $4876 \pm 146(\mathrm{~N}=6)$ & 0.514 & 0.620 \\
Duration of the first note of call A (s) & $0.405 \pm 0.054(\mathrm{~N}=4)$ & $0.288 \pm 0.130(\mathrm{~N}=6)$ & 1.950 & 0.091 \\
Duration of call B $(\mathrm{s})$ & $1.013 \pm 0.529(\mathrm{~N}=7)$ & $0.533 \pm 0.140(\mathrm{~N}=6)$ & 2.305 & $0.055^{*}$ \\
Pulse rate of the first note of call A $(\mathrm{p} / \mathrm{s})$ & $101 \pm 11(\mathrm{~N}=3)$ & $107 \pm 38(\mathrm{~N}=6)$ & -0.357 & 0.732 \\
Pulse rate of call B $(\mathrm{p} / \mathrm{s})$ & $32.0 \pm 4.5(\mathrm{~N}=6)$ & $44.0 \pm 1.5(\mathrm{~N}=6)$ & -6.274 & $0.001^{* *}$ \\
\hline
\end{tabular}

of competition, which caused divergence in mating behavior and larval development. The smaller size of individuals in the sympatric populations resulted in decreased offspring survival, female fecundity, and the sexual selection pressure on males (Pfennig \& Pfennig 2005). A result of this adaptive equilibrium is the coexistence of the two species in sympatry.

\section{Calling perches}

Calling sites are typical attributes of species and are correlated primarily with their morphology and size (DIXON \& HeYER 1968, Crump 1971, HöDl 1977). The fact that Dendropsophus microps males from Ribeirão Grande call from emergent vegetation may be related to structural differences between the habitats or a shift in micro-habitat selection, possibly due to competition for calling sites with other species. This hypothesis may also account for the observed differences in perch height between the two populations and could be verified with further observations and comparisons.

Due to plasticity in the use of calling sites, it is possible that a variation in the choice of calling perches may occur in closely related species in syntopy or in situations of high intra- and interspecific densities. BERTOLUCI \& RODRIGues (2002), for example, observed that Dendropshophus minutus and Physalaemus cuvieri used alternative calling sites when chorus sizes exceeded available perches.

Bertoluci \& Rodrigues (2002) recorded males of D. microps in the population of Ribeirão Grande calling from perches 30$70 \mathrm{~cm}$ high. This is consistent with the results of the present study obtained for the same population. This lower perch height may be related to the presence of $D$. giesleri, whose males were observed calling from perches $70 \pm 31 \mathrm{~cm}$ high $(\mathrm{N}=6)$ (LRF pers. obs.). This hypothesis remains to be tested, and if confirmed, it may reflect a phenomenon similar to that observed in Anolis lizards, which alter the elevation of their perches when there is another species of similar size living in the same area (Lister 1976).

\section{Acoustic analysis}

The advertisement call of Dendropsophus microps described by Heyer (1980) and by Heyer et al. (1990) is very similar to that described here, but we have added information about variation in the acoustical properties of both call types, including pulse repetition rate and call duration. POMBaL JR (2010) also provided a succinct description of the call of D. microps from a population from Ribeirão Branco, state of São Paulo, but he did not mention that there were two call types. Nevertheless, it remains unclear how $D$. microps males use the two call types.

In the D. parviceps group, the calls of Dendropsophus microps and $D$. giesleri are the only calls that have harmonic structure (HeYer 1980). A complete comparison of the advertisement call of $D$. microps with its sister species is given in Table 3. According to the phylogeny reconstructed by MотTA et al. (2012), using rRNA, genes $D$. giesleri is close to $D$. allenorum, but the relationship among the species inside the $D$. parviceps group is poorly resolved.

The main differences in acoustic traits between the two populations of the present study were in call B, which can be a target of evolutionary pressure. It is possible that these differences are associated with the presence of the sister species, $D$. giesleri, in Ribeirão Grande. The advertisement call of $D$. giesleri is very similar in structure to call B of D. microps (Figs. 10-11), making it possible to consider a hypothesis of acoustic character displacement, as already confirmed for other species (LittLejohn 1976). Under this hypothesis the coexistence of sister species might cause adjustments to the calling properties.

Considering all explanations above, call B was most likely under pressure to change because it could represent the main acoustic trait for species recognition and mate selection. Although this idea has yet to be tested, the increased pulse rate showed by the population from Ribeirão Grande could be only a compensation to enhance the visibility of males in the presence of the sister species, $D$. giesleri. As a dynamic trait, the pulse rate of call $\mathrm{B}$ of males from Boracéia can be measured 


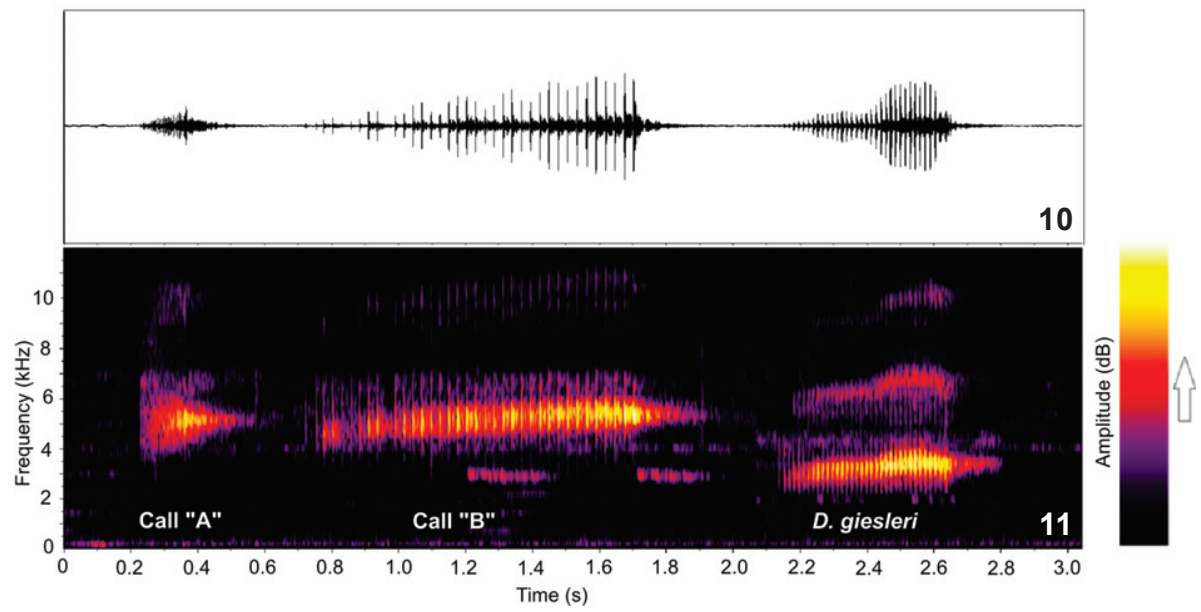

Figures 10-11. (10) Waveform and (11) spectrogram with both Dendropsophus microps call types (from Boracéia) and D. giesleri advertisement call from Ribeirão Grande recorded at 08:52 p.m. on October 28th 2010, SVL $=29.4 \mathrm{~mm}$, air temperature $=13.5^{\circ} \mathrm{C}$, humidity $=93 \%$.

Table 3. Acoustic properties of the advertisement call of some species of Dendropsophus parviceps group. The complementary data come from Duellman \& Crump (1974), Heyer (1980), Martins \& Cardoso (1987), Orrico et al. (2013).

\begin{tabular}{|c|c|c|c|c|}
\hline Species & Dominant frequency $(\mathrm{Hz})$ & Call duration (s) & Pulse rate $(p / s)$ & Number of notes \\
\hline D. allenorum & 3430 & 0.40 to 0.45 & 22 to 25 & 10 to 11 \\
\hline D. bokermanni & 4000 to 4652 & 0.23 to 0.28 & 100 to 190 & 5 to 19 \\
\hline D. brevifrons & 4152 to 5115 & 0.43 to 0.49 & 30 to 40 & $26-46$ \\
\hline D. giesleri & 3000 to 3600 & 0.3 & 100 & 1 \\
\hline D. microps* & 4972 (Call A) and 4913 (Call B) & 0.34 (first note Call A) and 0.67 (Call B) & 105 (Call A) and 38 (Call B) & 1 to 5 (call $A$ ) and 1 (call B) \\
\hline D. subocularis & 2200 & 0.53 & 43 & 3 to 20 \\
\hline D. timbeba & 3000 to 4200 & 0.6 & 18 & 10 \\
\hline
\end{tabular}

*Data from the present study.

during a playback experiment simulating a chorus of D. giesleri males. If this hypothesis (of compensation) is correct, an increased pulse rate of call B would be expected.

It is necessary to understand that acoustic signals are multidimensional and involve both spectral and temporal traits, whose relative importance for mate recognition may vary from species to species (ERdTMAnn \& AmÉzquita 2009) and their variation could increase reproductive isolation (LEMMON 2009). In this scenario, static acoustic properties (such as the spectral properties in our study) generally evolve under light directional or stabilizing selection, since they are commonly associated with conspecific recognition (GERHARdT 1991, Márquez et al. 2008).

\section{Variation of acoustic properties}

Temporal acoustic properties generally vary more than spectral properties because they may respond to temperaturerelated changes, and to social conditions, especially in calls with long pulse trains or long notes (Gerhardt \& Huber 2002,
Wong et al. 2004). On the other hand, spectral properties are strongly related to patterns associated with the occupation of frequency bands used for specific recognition (GERHARDT \& DAVIS 1988) and therefore tend to have low variation. A high variation in acoustic properties may not be adaptive when associated with pre-zygotic isolation mechanisms.

The fact that both populations show similar patterns of variation in spectral properties suggest that they may not be subjected to different selective pressures affecting these call traits. However, the pattern of variation of pulse rate for both types of calls were remarkably different between populations, with a special attention to a very small variation in the pulse rate of call B in the population of Ribeirão Grande. This result reinforces the hypothesis of compensation, where males subjected to interspecific competition increased pulse rate as an escape for acoustic visibility and recognition.

Our results show substantial differences between two populations of $D$. microps in body size, calling perch, and some 
call traits. These differences may be associated with the presence of the sister species, D. giesleri, in one of the localities. In order to verify this association, a larger number of populations need to be sampled, with the possible addition of experiments measuring female preference in sympatry and allopatry, as performed by Márquez \& Bosch (1997) for Alytes (Alytidae) and by Pfennig \& Ryan (2006) for Scaphiopodidae. An assessment of the degree of genetic differentiation between populations, considering the wide geographical distribution of $D$. microps in the Brazilian Atlantic Forest, could also help to explain the observed differences. Such an assessment would involve sampling of genetic, morphological and acoustical data from many populations. In addition, carrying out playback experiments to simulate the effect of a sister species as an acoustic competitor could clarify whether the difference in the pulse rate of call $\mathrm{B}$ between populations is a punctual consequence of the sympatry, since pulse rate is considered a plastic acoustic trait.

\section{ACKNOWLEDGEMENTS}

We are grateful to Fábio A. Martins for help during fieldwork. Special thanks to FAPESP by the doctoral grant and postdoctoral fellowship to LRF (process 2009/13987-2 and 2013/ 21519-4). JB is a researcher of CNPq (process 304938/2013-0). Partial funding for acoustical analyses was provided by Ministerio de Ciencia e Innovación, Spain, project TATANKA CGL2011-25062 (P.I.R. Márquez).

\section{LITERATURE CITED}

Bertoluci J, Rodrigues MT (2002) Utilização de hábitats reprodutivos e micro-hábitats de vocalização em uma taxocenose de anuros (Amphibia) da Mata Atlântica do sudeste do Brasil. Papéis Avulsos de Zoologia 42(11): $287-$ 297. doi: 10.1590/S0031-10492002001100001

Crump ML (1971) Quantitative analysis of the ecological distribution of a tropical herpetofauna. Occasional Papers of the Museum of Natural History University of Kansas 3: $1-62$.

Dixon JR, HeYer WR (1968) Anuran succession in a temporary pond in Colima, Mexico. Bulletin of the Southern California Academy of Sciences 67: 129-137.

Duellman WE, Crump ML (1974) Speciation in frogs of the Hyla parviceps group in the upper Amazon Basin. Occasional Papers of the Museum of Natural History, University of Kansas 23: 1-40.

Erdtmann L, Amézquita A (2009) Differential evolution of advertisement call traits in dart-poison frogs (Anura: Dendrobatidae). Ethology 115: 801-811. doi: 10.1111/ j.1439-0310.2009.01673.x

Faivovich J, Haddad CFB, Garcia PCA, Frost DR, Campbell JA, WheELer WC (2005) Systematic review of the frog family Hylidae, with special reference to Hylinae: phylogenetic analysis and taxonomic revision. Bulletin of the American Museum of Natural History 294: 1-240. doi: 10.1206/00030090(2005)294[0001:SROTFF]2.0.CO;2

Forti LR, Strüssmann C, Mott T (2010) Acoustic communication and vocalization microhabitat in Ameerega braccata (Steindachner, 1864) (Anura, Dendrobatidae) from Midwestern Brazil. Brazilian Journal of Biology 70(1): 211216. doi: 10.1590/S1519-69842010000100029

Frost DR (2014) Amphibian species of the world: an online reference. New York, American Museum of Natural History, v. 5.6. Avalaible online at: http://research.amnh.org/ herpetology/amphibia/index.html [Accessed: 23/02/2013]

Gerhardt HC (1991) Female mate choice in treefrogs: static and dynamic acoustic criteria. Animal Behaviour 42: 615-635. doi: 10.1016/S0003-3472(05)80245-3

GERHARDT HC (1994) The evolution of vocalization in frogs and toads. Annual Review of Ecology and Systematics 25: 293324. doi: 10.1146/annurev.es.25.110194.001453

GeRHARDT HC (2012) Evolution of Acoustic Communication: a Multi-Level Analysis of Signal Variation. Bioacoustics Journal 21(1): 9-11. doi: 10.1080/09524622.2011.647469

GerhardT HC, Davis MS (1988) Variation in the coding of species identity in the advertisement calls of Litoria verreauxi (Anura: Hylidae). Evolution 42: 556-565.

Gerhardt HC, Huber F (2002) Acoustic communication in insects and anurans: common problems and diverse solutions. Chicago, The University of Chicago Press, 531p.

HADDAD CFB, POMBAL-JR JP, BATISTIC RF (1994) Natural hybridization between diploid and tetraploid species of Leaf-Frogs, genus Phyllomedusa (Amphibia). Journal of Herpetology 28(4): 425430. doi: $10.2307 / 1564953$

Heyer WR (1980) The calls and taxonomic positions of Hyla giesleri and Ololygon opalina (Amphibia: Anura: Hylidae). Proceedings of the Biological Society of Washington 93: 655-661.

Heyer Wr, Rand AS, Cruz CaG, Peixoto O, Nelson CE (1990) Frogs of Boracéia. Arquivos de Zoologia 31: 231-410.

HöDL W (1977) Call differences and calling site segregation in anuran species from Central Amazonian floating meadows. Oecologia 28: 351-363.

Höbel G, Gerhardt HC (2003) Reproductive character displacement in the acoustic communication system of green tree frogs (Hyla cinerea). Evolution 57: 894-904. doi: 10.1111/j.0014-3820.2003.tb00300.x

LemMon EM (2009) Diversification of conspecific signals in sympatry: geo graphic overlap drives multidimensional reproductive character displacement in frogs. Evolution 63(5): 1155-1170. doi: 10.1111/j.1558-5646.2009.00650.x

LisTer BC (1976) The nature of niche expansion in West Indian Anolis lizards I: ecological consequences of reduced competition. Evolution 30: 659-676.

LitTlejohn MJ (1976) The Litoria ewingi complex (Anura: Hylidae) in south-eastern Australia IV. Variation in mating-call 
structure across a narrow hybrid zone between L. ewingi and L. paraewingi. Australian Journal of Zoology 24: 283293.

Márquez R, Bosch J (1997) Male advertisement call and female preference in sympatric and allopatric midwife toads (Alytes obstetricans and Alytes cisternasii). Animal Behaviour 54: 1333-1345. doi: 10.1006/anbe.1997.0529

Márquez R, Bosch J, Еeкhout X (2008) Intensity of female preference quantified through playback setpoints: call frequency versus call rate in midwife toads. Animal Behaviour 75: 159-166.

Martins M, Cardoso AJ (1987) Novas espécies de hilídeos do Estado do Acre (Amphibia: Anura). Revista Brasileira de Biologia 47: 549-558.

Morais AR, Batista VG, Gambale PG, Signorelli L, Bastos RP (2012) Acoustic communication in a Neotropical frog (Dendropsophus minutus): vocal repertoire, variability and individual discrimination. Herpetological Journal 22: 249-257.

Motta AP, Castroviejo-Fisher S Venegas PJ, Orrico VGD, Padial MJ (2012) A new species of the Dendropsophus parviceps group from the western Amazon basin (Amphibia: Anura: Hylidae). Zootaxa 3249: 18-30.

Orrico VGD, Duellman WE, Souza MB, Haddad CFB (2013) The Taxonomic Status of Dendropsophus allenorum and Dendropsophus timbeba (Anura: Hylidae). Journal of Herpetology 47(4): 615-618. doi: 10.1670/12-208
Pfennig KS, Pfennig DW (2005) Character displacement as the 'best of a bad situation': fitness trade-offs resulting from selection to minimize resource and mate competition. Evolution 59: 2200-2208. doi: 10.1111/j.0014-3820.2005.tb00928.x

Pfennig KS, Ryan MJ (2006) Reproductive character displacement generates reproductive isolation among conspeciûc populations: an artiûcial neural network study. Proceedings of the Royal Society B 273: 1361-1368. doi: 10.1098/ rspb.2005.3446

Pombal JR JP (2010) O espaço acústico em uma taxocenose de anuros (Amphibia) do sudeste do Brasil. Arquivos do Museu Nacional do Rio de Janeiro 68(1-2): 135-144.

Ryan MJ, RAND AS (1993) Species recognition and sexual selection as a unitary problem in animal communication. Evolution 47(2): 647-657.

Toledo LF, Haddad CFB (2005) Acoustic Repertoire and Calling Behavior of Scinax fuscomarginatus (Anura, Hylidae). Journal of Herpetology 39(3): 455-464. doi: 10.1670/139-04A.1

WeLLS KD (1977) The social behavior of anuran amphibians. Animal Behaviour 25: 666-693.

WeLLS KD (2007) The ecology and behavior of amphibians. Chicago, The University of Chicago Press, 1148p.

Wong BBM, Cowling ANN, Cunningham RB, Donnelly CF, Cooper PD (2004) Do temperature and social environment interact to affect call rate in frogs (Crinia signifera)? Austral Ecology 29(2): 209-214. doi: 10.1111/j.1442-9993.2004.01338.x

Submitted: 25 June 2014

Received in revised form: 31 March 2015

Accepted: 12 April 2015

Editorial responsibility: Mauricio O. Moura 